\title{
Kidney Cancer pT2b TNM Finding v8
}

National Cancer Institute

\section{Source}

National Cancer Institute. Kidney Cancer pT 2b TNM Finding v8. NCI Thesaurus. Code C140290.

Kidney cancer in which the tumor measures more than $10 \mathrm{~cm}$ in greatest dimension and is limited to the kidney. (from AJCC 8th Ed.) 